\title{
THE FALL OF PRESIDENT MUHAMMED HOSNI MUBARAK AND THE PROSPECTS FOR DEMOCRATIZATION IN EGYPT
}

\author{
Oleh: \\ Nuril Khasyi'in \\ Prodi Hukum Tatanegara Fakultas Syariah Universitas Islam Negeri Antasari, \\ Banjarmasin, Jalan Ahmad Yani Km. 4.5 Banjarmasin, Kalimantan Selatan, Indonesia \\ E-mail: khasyiin2015@gmail.com
}

\begin{abstract}
Abstrak: Studi ini membahas kejatuhan rezim Mubarak dengan melihat beragamfaktor penyebab kehancuran legitimasi Mubarak dengan menganalisa pergantian rezim otoriter kearah demokrasi. Gerakan aksi protes 25 Januariini, menjadi usaha nyata untuk mewujudkan impian demokrasi itu. Penelitian ini diawali dengan; usaha Mubarak dalam mencari legitimasinya mendukung kekuasaan barunya dari pihak-pihak oposisi warisan Sadat. Dilanjutkan dengan faktor-faktor yang menyebabkan pendukung Mubarak, berpindah menjadi kelompok oposisi yang justru akan menjatuhkannya. Lalu diakhiri dengan kejatuhan Mubarak itu sendiri, setelah Mubarak gagal memberikan konsensikonsensi yang ditawarkannya. Oposisi dari kelas menengah, bawah dan jugabeberapa elit atas (militer) telahmenjadi aktor utama dalam menumbangkan rezim Mubarak ini. Rezim Mubarak, didominasi oleh kelas-kelas penguasa yang bekerjasama dengan pengusaha dalam mengambil sumber-sumber kekayaan alam Mesir. Penyelewengan kelas atas seperti korupsi, manipulasi pemilu, penangkapan pihak-pihak oposisi dan pelanggaran HAM menjadi hal yang lumrah dalam rezim ini. Pengusaha menjadi partner dekat Mubarak untuk menggali sumber-sumber ekonomi negara. Setelah terjadi krisis ekonomi, kelas-kelas subordinan kemudian bangkit melawan kelas-kelas dominan. Studi ini menggunakan teori replacement dan legitimasi, dengan memakai sumber-sumber pustaka, surat kabar dan jurnal-jurnal untuk membantu memberikan penjelasan yang tajam. Hepotesa dari penelitian ini; pendukung Mubarak akan berpindah menjadi oposisi, jika kebutuhan dan kepentingan mereka tidak terpenuhi, lebih khusus berkaitan dengan kebutuhan ekonomi. Perubahan sikap Mubarak yang lebih mementingkan kemakmuran pengusaha dari pada publik, membuat Mesir menjadi negara yang terpuruk dalam hal ekonomi. Selain itu, penyelewengan kekuasaan oleh pemangku jabatan, membuat pihak yang teraniaya (subordinan) akan terusmaju bergerak melawan kekuasaanrezim otoriter.
\end{abstract}

Kata Kunci: Mesir, Rezim Otoriter, Krisis Ekonomi, Perubaban Rezim, Kejatuban Mubarak. 


\begin{abstract}
This studydiscussesfall ofthe Mubarak regimeby looking thefactorsandanalyzehow the authoritarian regime changetowarddemocracy. January 25, becamea realefforttorealize that dream. This studybegins witha discussion; effortsin seekingMubarak legitimacytosupport hispowerfromSadat'sopposition, and continued withthe factors thatled Mubarak's support, movedto be opposition. It'sdescribes theendofMubarakregime. His Oppositionfrom themiddle class, lower classandsomeupperclass(military). They are becamea majoractorinfall ofthe Mubarak regime. Mubarak's regime is dominated by the ruling classes in cooperation with employers in taking the natural resources of Egypt. Upper-class diversion such as corruption, electoral manipulation, arrest opposition parties and human rights abuses became commonplace in this regime. Employers in this regime to explore the economic resources. After the economic crisis, these classes subordinan then rose up against the dominant classes.This study uses a theoretical approach (replacement and legitimacy). With this both theoreticals approach will help the authors provide a powerful explanation of the fact that the field has been meticulous writer. Hepotesa of this study was Mubarak's supporters will move into the opposition, if their interests and needs are not met anymore. Mubarak attitude change employers are more concerned with the prosperity of the public, abuse of power by officers, with the pressure of economic crisis, will force the opposition to end with this authoritarian regime.
\end{abstract}

\title{
Keywords: Egypt, Authoritarian Regime, Economic Crisis, Regime Change, Fall Mubarak.
}

\section{Introduction}

This journal trying to describes the cause of the resignation of Husni Mobarak as the President of Egypt. Mubarak decides to resign after he lost his legitimacy. It can be seen by his failure and incompetence against the opposition and it make the movement of anti-Mubarak stronger. At the beginning of his leadership, Mubarak tried to embrace all groups in Egypt, especially to help him facing economic and security crisis at that moment. Those entirethings are to strengthen his legitimacy from the opposition and also from lower middle class in Egypt. After 1990, Mubarak starts to looking his legitimacy from private area with liberalize and privatize government enterprises. This condition, successfully change the image of Mubarak, from 
jumburiyya (public) support to rijal amal (capital owners) support.

At the same year, Mubarak regime's power abuse has also increased. The regimes were free to do some repression for those who considered as opposition through martial laws. With the law, repression and human right violation are becoming more frequent, such as repression to intellectuals, journalists, and students. Those of them are middle class which considered danger because they act critical to the regimes. They revealed the facts of the regime such a corruption, election fraud, drug dealer, prisoner abuse and so on. Those middle class getting stronger because the lower classes also givethem support through their actions against the government. Understand this condition, the regime fight them back to retain their power in Egypt and also to prevent the development of this movement.

In May 25 $5^{\text {th }}$ 2005, the security guards attack the protesters who oppose the proposed amendment to limit the election with one candidate only ${ }^{1}$. In

1 Security Forces Attack Opposition
Demonstrators,Human Rights Watch Press,

somecase, on the election in 2005, it can be seen by the record that the security guard prohibited the voters entering the polling station. In April 24th 2006, the police strike the activists which gathered in judge's association club, and in a days later, they arrested at least 51 members of the club. Besides that, the regime also holds the state security prosecutor through martial laws on charges of participating with the opposition and held the meetings for insulting the president, spreading the propaganda and harmful rumors for the state. ${ }^{2}$

With the martial laws in Egypt, the regime has allowed to arrest everyone or group who considered suspicious. With it, the government have a total authority to arrest and torture person without trial because considered as betrayer and endanger the stability of the country. Moreover, the amendment of legal laws 116/1981 and 109/1971

\footnotetext{
August $\quad$ 01, 2005, web: <http://www.hrw.org/en/news/2005/08/01/e gypt-security-forces-attack-oppositiondemonstrators>, Oktober 12, 2011.

${ }^{2}$ Egypt: Troops Smother Protests, Detain Activists, Human Rights Watch Press, May 5, 2006, web: <http://www.hrw.org/en/news/2006/ 05/05/egypt-troops-smother-protests-detainactivists>, Oktober 12, 2011.
} 
also expand the responsibilities of the police from maintain public safety to maintain public order. ${ }^{3}$

The regime further strengthen the protection, particularly to middle and lower class. They even started making arrests, jail, and fired (government employees) often to who considered as a betrayer. With this condition, not surprisingly it found $12.000-15.000$ political prisoners. ${ }^{4}$ Based on number from Ibnu Khaldun Egypt Center, the number of political prisoners are grow up from 8000 in 1992 to17.191 in 1993. Based on Human Right Organization of Egypt, the number of prisoner who arrested (no political reason) are increased from 5000 in 1990, to 10.000 in 1992 and 16.000 in $1995 .{ }^{5}$

What the regime did have made worse the legitimate of Mubarak in front

3 Ouda, Jihad, Negad el-Borai, and Hafez Abu Saada, A Door onto the Desert: Egyptian Legislative Elections of 2000, Cairo, United Group and Friedrich Naumann Foundation, 2001, p. 25.

${ }^{4}$ Kassem, Maye, Egyptian politics: the dynamics of authoritarian rule, Lynne Rienner, USA, 2004, p. 40.

5Ibn Khaldun Center, Al-Mujtama' El-Madani wa al-Tahawnul El-Dimuqrati fi al-watan al-'arabi, al-taqrir al-sanawi 1994 \& 1996, Cairo, 1997, p. 63-66. of the people Egypt. On this journal, the author dividing the three periods of the history of Husni Mubarak, as follows. The first period is called accommodation and tolerance periods. After Mubarak gets the position as the $4^{\text {th }}$ President of Egypt. He tried to build his power legitimate by the opposition in Sadat regime (The earlier President). In this period, Mubarak is more delicate and wisely in calming the opposition. The second period called as confrontation and repression moment, where the relation between Mubarak and the whole class in Egypt are clashes and conflict began to emerge. On this period, Mubarak began to leave the public interest and pro to private group al Gamal group (Mubarak Sons) and it's affect to his legitimate in Egypt. The third period is about the fall of Mubarak as the climax of legitimate crisis of him.

Those three will be the basic explanation the reasons;why Mubammed Hosni Mubarak charged back from bis position as president of Egypt?. Based on this research, the author argued that the economic crisis in Egypt is the one of 
causes in fall of Mubarak's regime. This argument also stated in Huntington'sin his book: Third Wave of Democratization; that, "Economic development creates the foundation for a democratic regime in the long run. In the short term, rapid economic growth and the economic crisis may weaken the authoritarian regime. If economic growth takes place without the economic crisis, it is slowly evolving democracy. When the shaking growth or economic crisis without achieving prosperity in the transition zone, the authoritarian regime itself would collapse, ... ${ }^{6}$ The issue of economic crisis in Mubarak periods will be an interesting analysis to seeing what happen in Egypt.

\section{Hosni Mubarak as the President of Egypt}

The first period called as an accommodation and tolerances period. This period started with the assassination of Anwar Sadat as the President of Egypt. There are three main problems that left by Sadat. First is related to Egypt's policies that always

\footnotetext{
${ }^{6}$ Asril Marjohan, 'Gelombang Demokratisasi Ketiga', Eds: II, Jakarta, Pustaka Utama Grafiti, No. 328/95, 1997, p. 180. In Third Wave of Democratization, Huntington.
}

associated with USA. Second is economic crisis and the number of corruption. Third is the policy of reconciliation with Israel, to dealing with that condition, Mubarak then tried to strengthen his legitimate through and pay more attention to those problems.

The effort of Mubarak to strengthen his legitimate last between 1981-1990. On that period, Mubarak trying to make conciliation with people who considered as government oppositions. He made approach to the whole class in Egypt. Fortunately, Mubarak was in a position secure from political side when completing the demands of the opposition is the legacy of Sadat, it because, during his career Mubarak doesn't have any particular disagreement with the opposition. Moreover, he also doesn't belong to free officer who gained streght in 1952. With that thing, Mubarak can be more independent on his leadership.

On his first speech, Mubarak said he will continue Sadat policies, but in a soft way, wisely and dynamically. The speech got attention by society because it figures more prudent and tolerant 
policy for the pros and cons of Sadat. This speech was followed by completing his first attempt polemek legacy of Sadat, the dependency relations between Egypt asnd United States. In this case, mubarak decides to refuse the official development assistance from United Stated for $\$ 500$ million in 1983 , it related to the development of navy. Moreover, Mubarak also decides to not joint with United states operation milter to face Libya. The Rejection is accompanied by economic recovery in the public sector, and also the resistance to corruptions cost the state. On the economic development, Mubarak was increasing the infrastructures projects related to reconstruction, such as communications, transportation, housing, etc. He also improves Egyptian workforce dispatch and creating a partnership with Iraq, in order to increase the Egypt's economics revenue. Then, Mubarak attracts foreign investors, as much as possible to satisfy the people of Egypt. Mubarak also promised will create more job opportunities for students who just graduated. He stressed that he will rehabilitate the public sector, to maximize the productivity and promote investment, because as he pointed out, that's the only and the right solution the economic recovery.

A campaign to fight against corruption is also directly proved by capturing Sadat's brother, Ismat, who later trial in 1983. On this period, Mubarak tends itself as an executer of the law. It figuresout, that the regime knows no nepotism; all are equal before the law. To strengthen the support of Sadat's political opponents, In 1982, Mubarak frees the political activist who was arrested and jailed by Sadat; more than a thousand prisoners from various groups community, such as religious, journalists, students, members of professional syndicates and trade unions released. This kind of attitude, another is to ease tension between state relations with opposition.

As related to the treaty with Israel, Mubarak committed to continue the Camp David treaty, but at the same time, he was sure that peace is not translated into a complete normalization 
of the social or economic relations.Mubarak assured that Egypt would not be in rush toward the real peace, until Egypt returned into it territories since 1967, and the Palestinians return to their homeland. This sentiment was confirmed in 1982 when Mubarak immediately withdrew its ambassador in Tel Aviv in order protest against the Israel invasion of Lebanon. Moreover, Mubarak also sought to rewarm the Egyptian relations with the Arabian countries. With thissuccessful effort, Mubarak looks to be the support of public welfare in the welfare and prosperity of Egypt.

The final effort is to strengthen the support of top-class by giving permission to open the arms industry in addition to military and defense equipment. Also provide the food industry, self-sufficiency and other community needs such as kitchen appliances, farming, farms, plantations and others. Based on these efforts, the legitimacy of the Mubarak nurtured and get lots of support from all groups of community structure.

\section{Crisis of Mubarak's Legitimacy}

The second period, called the period of confrontation and repression. The period begin at 1990 s to 2005 s. This was a period when the dynamics of relationships that Mubarak's formed to strengthen his legitimacy began to disintegrate, it shown bythe economic collapse which is a consequences of the authorities' corruption and the businessmen who taking natural resources in Egypt. Gamal Mubarak is the ultimate symbol of wealth imbalance between workers and private sector elites, the symbol of corruption and greed in Egypt. The emergence of business in the NDP, ${ }^{7}$ in government and Al-Sha'ab Magles (House of Representative), make the country as a source of income to enrich them. A biographer of Egypt, Aladdin El-Aasar, estimates that the Mubarak family savings deposits from $\$ 50$ to $\$ 70$ billion dollars. ${ }^{8}$ It also happens with the

${ }^{7}$ National Democratic Party (NDP).

${ }^{8}$ Aladdin Elaasar, Egyptians Rise Against Their Pharoah,Huffington Post,January 28, 2011, web: $<$ http://www.londonthenews.com/news/Worl d/20110128/19166904/Aladdin-ElaasarEgyptians-Rise-Against-Their-Pharoah.htm>, Oktober 20, 2011. 
other authorities in this regime. For example, Ahmed Ezz wealth 'as former Secretary of the NDP estimated $£$ E18 billion Egyptian pounds ${ }^{9}$; Ahmed Ezz monopolizing the steel industry in Egypt by holding more than $60 \%$ of market share. ${ }^{10}$ The wealth of former Housing Minister Ahmed El-Maghraby is also estimated at more than $£$ E11 billion Egyptian pounds, ${ }^{11}$ the former Minister of Tourism Zuhair Wealth Garrana estimated $\&$ E13 billion Egyptian pounds; the wealth of former Minister of Trade and Industry, Rashid Mohamed Rashid, estimated \& E12 billion Egyptian pounds, 12 and the wealth of former Interior Minister Habib al-Adly estimated $\&$ E8 billion Egyptian pounds. ${ }^{13}$ Other who accepted a had

\footnotetext{
${ }^{9}$ Obama optimistic about Egypt as negotiators make concessions. AHN. February 9, 2011, web: $<$ http://gantdaily.com/2011/02/07/obamaoptimistic-about-egypt-as-negotiators-makeconcessions/>, October 20, 2011.

${ }^{10}$ The Report: Egypt 2007, Oxford Business Group, January 2007, web: $<$ http://www.oxfordbusinessgroup.com/produ ct/report/report-emerging-egypt2007>, October 20, 2011.

${ }^{11}$ Ibid.

${ }^{12}$ Ibid.

${ }^{13}$ Corrupt files in the cause of the outbreak of the Revolution, web: <http://holafootball.blogspot.com/2011/02/c
}

received bribes $£$ E20 million Egyptian pounds is former Secretary of Housing and the attorney general, Mohamed Ibrahim. ${ }^{14}$ CAA also revealed many cases of irregularities and corruption amounting tens of millions of Egyptian pounds in the General Federation of Trade Unions led by Hussein. ${ }^{15}$

\footnotetext{
orrupt-files-in-cause-of-outbreak-of.html>, November 25, 2011.

14 Corruption index 2010 from Transparency International: find out how each country compares, bisa diakses di: <http://www.guardian.co.uk/news/datablog/2 010/oct/26/corruption-index-2010transparency-international $>$, November 25, 2011.

${ }^{15}$ Harik Iliya, "Economic Policy Reform in Egypt", Gainesville:University Press of Florida, 1997, pp. 18-19.
} 


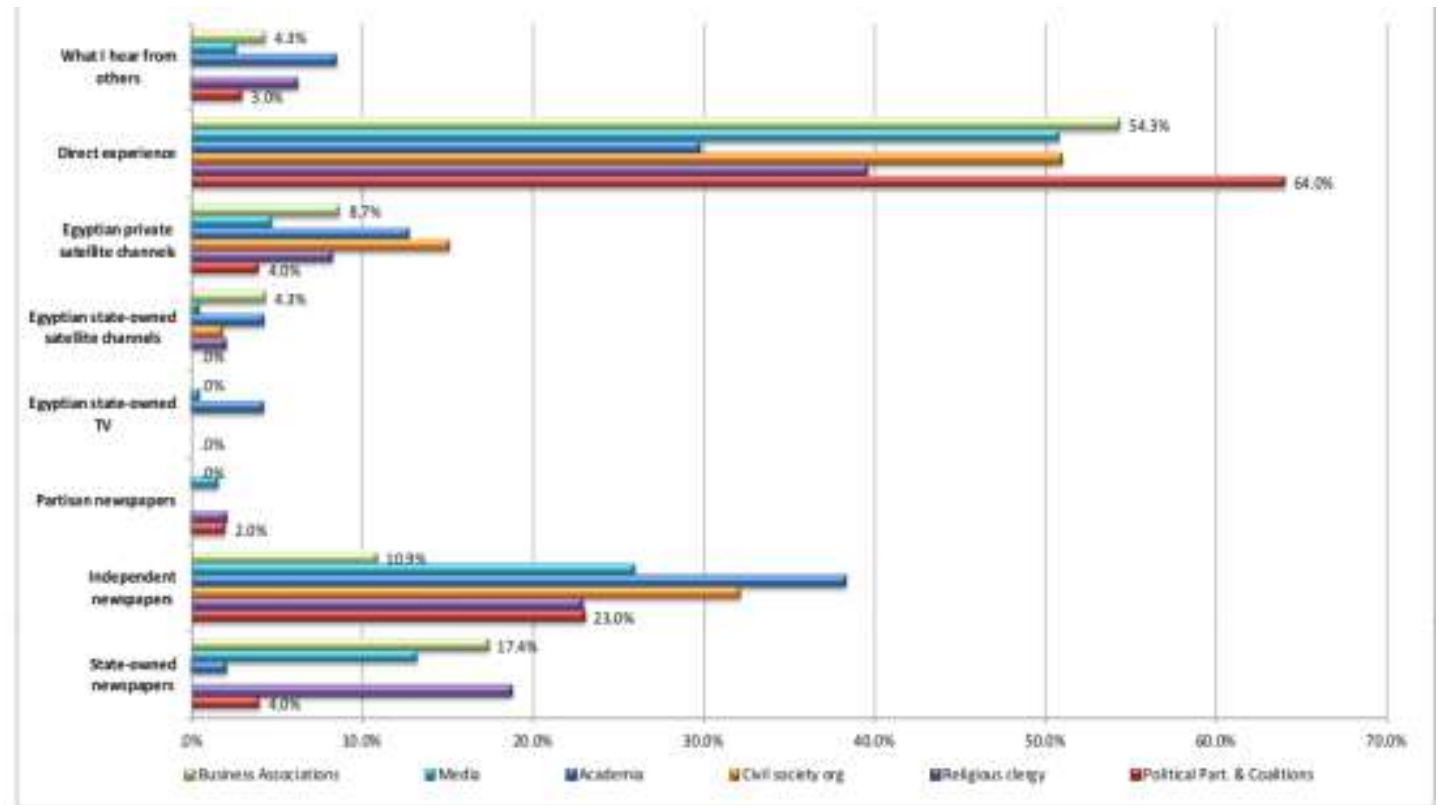

Public opinionabout level of corruption concerned, it because of the inflation in Egypt. ${ }^{16}$

begin to affect the welfare state, both

Beside of the ever-expanding wealth of entrepreneurs of the regime, the Economy of Egypt is suffering and ready to collapse, it shown by the increasing of unemployment and the national debt pile, food crisis. The under pressure from the World Bank, IMF, and the United States relating to the reconstruction of the Egyptian economy are caused it. ${ }^{17}$ The fund of the national budget to support the SOEs also

\footnotetext{
16 Source: Ahram Center for Political and Strategic Studies, Suported by the Center for International Private Enterprise.

${ }^{17}$ Harik Iliya, "Economic Policy Reform in Egypt", Gainesville:University Press of Florida, 1997, pp. 18-19.
} quantitatively and quality. This can be seen with the sales of almost 85.300 public sector enterprises to the private sector in 1997.

Thus, The Debt was rising about 150 percent, and it became the highest debt in the world at that moment. Realize the condition, Mubarak was forced cut the economics budget up to $\$$ 20 billion, and was forced to cut annual interest payments of debt of $\$ 2$ billion in the next ten years. ${ }^{18}$ The evidence of this crisis can be seen from the data

${ }^{18}$ Nora Bensahel and Daniel L.Byman, The Future Security Environment in the Middle East: Conflict, Stability, and Political Change, United States, Air Force, 2004, p. 79. 
showing that the Egyptian spending on basic social services dropped from about 6 percent in 1990 to 4 percent in 1993. In addition, the unemployment rate also increased from $10.3 \%$ in 2004 to $11.2 \%$ times more college graduates than available jobs. ${ }^{21}$

In the middle of the conflict, the government has struggled to maintain their power. Mubarak's regime has

Source: International Monetary Fund - 2011 World Economic Outlook

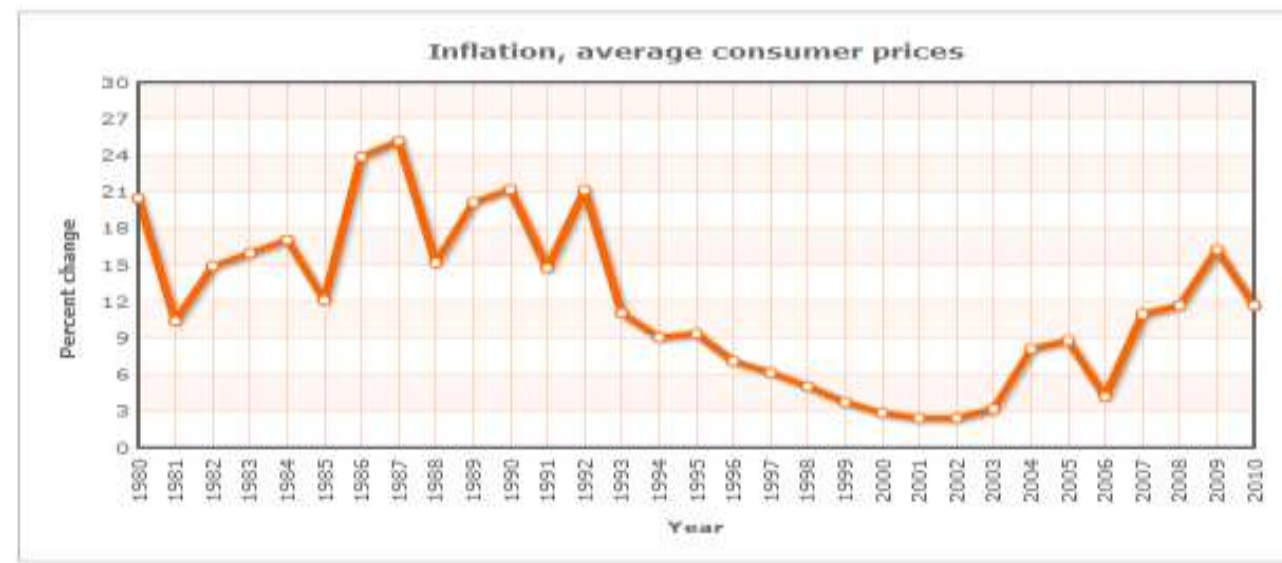

in $2005 .{ }^{19}$

\section{Egypt inflasionfrom 1980-2010.20}

Besides the economic problems, the illiteracy rate in Egypt is still high, jobs are harder and the social disparities are high. Unemployment is driven by the increasing thenumber of the youth, with the graduated number is $4 \%$ per annum, making Egypt asa country that has 10

\footnotetext{
${ }^{19}$ Dau Khalifa Ali and El-Amach Hussein, Social Safety Nets: The Social Development Fund in Egypt, pp. 102-103.$$
20
$$

http://www.indexmundi.com/egypt/inflation_r ate_\%28consumer_prices $\% 29$. html.September 12, 2011.
}

always tried to manipulate the elections. In addition, the regime also tried to pressure and paralyzes opposition groups who are trying to win and change the regime. According to the Independent Committee on Election Monitoring (ICEM), ${ }^{22}$ the election of 2005 was full of fraud. The thugs

\footnotetext{
${ }^{21}$ The long-term economic challenges Egypt must overcome, web: <http://www.marketplace.org/topics/world/ne w-egypt/long-term-economic-challenges-egyptmust-overcome>, September 09, 2011.

${ }^{22}$ Independent Committee on Election Monitoring, Press Statement, November 15, 2005, web: <http://www.ndi.org/files/1943_eg_icemfirst_ 110905.pdf>, October 12, 2011.
} 
prevent the voters to enter the polling stations on district of Beni Sueif and Nasser. In the same district in Rab'ah El Adawe'ah, the polls even closed for several hours to prevent the MuslimBrotherhood (MB) collecting votes. The International Republican Institute and the Washington-based NGO affiliated with the Republican Party even witnessed the brutal and bloody fights between supporters of candidates, but the police actually looks strangely silent and refused to intervene. ${ }^{23}$

There are at least 18 cases of security forces that entered the polling place, confiscate the camera, beating even the arrest of foreign journalists. ${ }^{24}$ Moreover, the intimidation of voters is increase, along with reports of beatings

\footnotetext{
23 International Republican Institute 2005 Parliamentary Election Assessment in Egypt, International Republican Institute, Edisi; November 15-21, 2005, web: <http://www.iri.org/sites/default/files/Egypt $\% 27 \mathrm{~s} \% 202005 \% 20$ Parliamentary $\% 20$ Elections $\% 20$ Assessment $\% 20$ Report.pdf $>$, October 12, 2011.

${ }^{24}$ More than 50 Journalists and Media Workers Harassed, Some Beaten while Covering Elections, Reporters Without Borders, December 9, 2005, web: <http://en.rsf.org/egypt-more-than-50journalists-and-media-09-12-2005,15881.html>, October 12, 2011.
}

and arrests of journalists who involved in monitoring the elections. ${ }^{25}$ The attitude of this regime eliminates the sympathetic attitude of the Mubarak's leadership.

The entrepreneurs of the NDP are getting a lot and the style of Sadat's economic began to return. When the role of the Mubarak's business community are increase, the entrepreneurs become the functionalist that supports of the régime. Mubarak seen as giving many opportunities to the entrepreneurs who's invest in government, especially in certain areas. It is proved that the entrepreneurs have a strong relationship with the regime. For example, Ahmed 'Ezz, is a business owner iron and steel. Similarly, Mohammed Abu El-'Anei, friends of Gamal Mubaraka great businessman. Also Gamal Mubarak, he is not only a businessman but also the general secretary of the National Democratic

\footnotetext{
${ }^{25}$ Letter from Human Rights Watch to Secretary of State Condoleeza Rice, Regarding Department of State Comments on Egyptian Elections, December 01, 2005, web: $<$ http://www.hrw.org/en/news/2005/12/01/1 etter-secretary-state-condoleeza-rice-aboutdepartment-state-comments-egyptian-elec $>$, September 12, 2011.
} 
Party (NDP). Their proximity to the ruling regime, enabling them to build the business capital, only through a bank loan without risking your own money.

At the first of his reign, Mubarak still hesitated to give the role of entrepreneurs in the country. It can be seen from his caution when replacing the public sector with the private sector. He should to do that, to avoid any foreign pressure when applying the economic liberalization. However, after seeing the importance of the role of employers in a regime, it making Mubarak began to adopt liberalization foreconomic of Egypt. After that the role of business community's on Egypt are increased and stronger.

Then, entrepreneur becomes functionalist, in order to survive the regime. For example, Gamal Mubarak, he frequently traveled to the United States to discuss about how to to manipulate the Egyptian economy. The intervention of foreign capital in Egyptian politics, eventually led to the growing social gap between foreign businessmen and Egyptian communities.
Mubarak gives many opportunities for investment businessmen in his administration, particularly in certain areas (such as industrial activities). This showed up that the investments of entrepreneur are rises, because theyestablish good relations with the ruling regime.

With all these things, private sector growing faster than the public sector during the years of Mubarak, and it contributes more than a half of GNP (Gross National Product). The businessmen have evolved in such a way, thus the cabinet which was formed in July 2004 made two ministers with a business background; Ahmed ElMaghrabi (Minister of Tourism) and Rashid Mohamed Rashid (Minister of Industry). In 2005, there are eight ministers and in 2006, rising to fifteen ministers, nearly half of the cabinet in Magles Sha'ab.

The Entrepreneurs with the regime are controlling the economic, political, and social resources in Egypt. For example, the prospective businessman or entrepreneur has started 
a block that looks at the general election since the 1990s, and also in the 1995 elections. The owners of capital in trade (import/export) generally seek election in the coastal districts such as Port Said, Ismailia, Damyetta, etc. The agricultural sector, they prefer in rural areas such as Zaqaziq and in industrial sector, candidates focus on major cities such as Cairo and Alexandria. These showing that Mubarak orientation have shifted from promoting the people's economy to be in favor of entrepreneurs

Generally, each district has three to five entrepreneurs who are competing for the same seat. This campaign occurs not only between employers official NDP candidates, but also involving a real entrepreneur-independent candidates, as well as other candidates who do not find themselves from the NDP representative. In 1995 there were thirtyseven influential members who's profession as a businessman in $\mathrm{Al}$ Sha'ab Magles. Five years later, the entrepreneurs hold 77 seats or $17 \%$ in Magles Al-Sha ‘ab plus seven committee of economy affair who all came from entrepreneurs. The Egyptian business- men continue to strengthen their intimate relationships with high-ranking government officials, even presidents. In this case, many close relatives of top officials becoming big business owners. They can do so because they have the capital and political power by the ruling elite, as Gamal Mubarakwho formed a new faction called the Gamal Mubarak entrepreneurs group. This new camps will be faced with the old group of entrepreneurs who have a longer military deal with Egyptian companies.

The new entrepreneurs under groups of Gamal Mubarak are stronger and growing more than the old one (the military), it because the NDP businessmen have a special protection from the President. This situation makesstrife and divisions among the ruling elite. The military feel losses, particularly which related to selfsufficiency efforts and infrastructure development that taken by the group (Gamal Group). From here,the class cracks up (military against the Mubarak regime), and become rational, if one day the military no longer favor to the regime. 


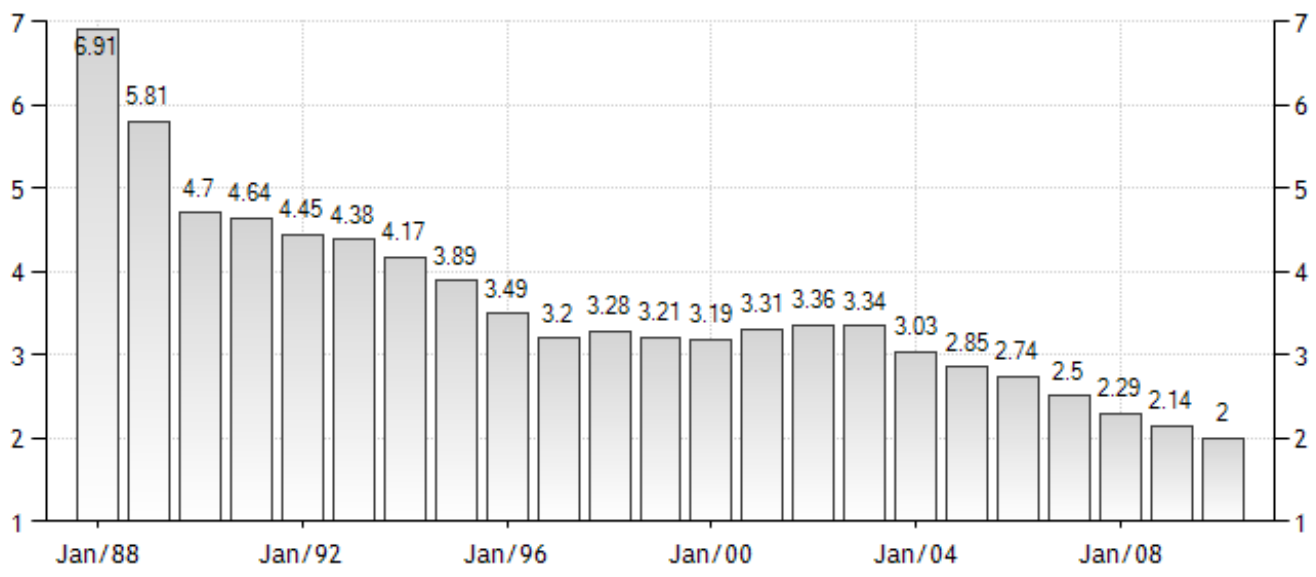

Military expenditure in Egypt. ${ }^{26}$

masses, for the purpose of overthrowing Mubarak. Seeing this

\section{Fall of Mubarak}

The third period called the period of the overthrow of the Mubarak regime. This was a period in which the mounting anger of the masses against the regime. After the Tunisian succeeded in overthrowing the regime of Ben Ali, Egypt would be the next country that will participate to overthrow the Mubarak regime. January $25^{\text {th }}$ is a day of the outbreak of mass protests in Maidan Tahrir. Peoples choose this day as their protests namely as a form of protest, to the treatment and abuse of police to the community (January $25^{\text {th }}$ is the police day). The protest was attended by thousands and even millions of the

26 Military expenditure in Egypt, <http://www.tradingeconomics.com/egypt/ military-expenditure-percent-of-gdp-wbdata.html>,08 April 2012. condition, Mubarak finally offered concessions to the opposition parties is to appoint a new government (the transitional government) and dissolved the old ministers. Furthermore, Mubarak also appointed vice president Omar Suleiman, and promised not to run again on next election. These concessions were not bearing fruit, even the amount of mass in Tahrir just more and more. Looking the conditions are increasingly tenses, Mubarak took the next step to dissolve the force (coercion) of the demonstrators. This forced led to hundreds dead and thousands injured. Seeing the condirion, the world (such as the U.S. and Europe), began appearing to interfere take part, by 
asking Mubarak to step down immediately as a President.

Based on the various perceptions, the fall of Mubarak is certainly can't be separated from the problems of the distribution economic inequality, particularly the division of job land in a fair and equitable. Unequal distribution will continue to get worse, after the rise of inflation and global crisis. Global crisis in 2007 2008, has led to a wave of conflict among people of lower class, middle class and upper class. Therefore, this crisis has had a huge impact and effect control every aspect of the economy of Egypt, came to the field of tourism, of migrant workers, export earnings, and investment. In response to this economic oppression, the students formed from 6 April Youth Movement, went off his campaign rallies and with protests to demand an economic prosperity via microblogging. Microblogging which includes Facebook, Twitter, and Youtube become a tool to spread the word and discuss the state of Egypt. ${ }^{27}$ For

27 The Arab Spring's Cascading Effects, web: $<$ http://www.millermccune.com/politics/the-cascading-effects- example, Asmaa Mahfouz, became one of the activists who were able to persuade other activists and groups for the middle class down to the Maidan Tahrir on January 25.28 On his action on Youtube, Asmaa convey, that there are 4 poverty in burned himself to demand improved labor costs. In addition, he also explained that the people of Egypt do not be afraid to claim their rights to gather together and take to the streets protesting peacefully.

This invitation was fruitless, because the action campaign on Facebook as well followed by a young executive Ghanim Wael in Google Company. Said Khaled Ghanim picked up the story of a murdered police as a form of protest and propaganda. There are 225,000 people Facebooker activists, then replace them with a photo profile photo Khaled Said. ${ }^{29}$ This condition, gained much sympathy

of-the-arab-spring-28575/>,December 10, 2011.

${ }^{28}$ Facebook post that sparked Egypt revolution, web: <http://ibnlive.in.com/news/facebookpost-that-sparked-egypt-revolution/142328-

2.html>, December 10, 2011.

${ }^{29}$ Mona Eltahawy, On Khaled Said and his effects on Egyptian bloggers and activists, Huffington Post , June 25, 2010, web: <http://mediaoriente.com/2010/06/25/onkhaled-said-and-his-effects-on-egyptianbloggers-and-activists/>, January20, 2012. 
from intellectuals, such as Yusuf Qaradawi and Al Baradie. And they then take the same action;demonstrated took to the streets, and called on all other Egyptians who remained in the house, to be joined with the demonstrators. Both of these important figures (Al Baradie and Qaradawi), despite having two different backgrounds, but they are from the same organization, namely the Muslim Brotherhood (MB).

The protests in January $25^{\text {th }}$, apart from the middle class, this action also supported by lower-class opposition, namely the resistance of the workers and the poverty. In example, January $28^{\text {th }} 2011$, the widespread labor strikes over the whole of Egypt. More than 500 employees of the Red Crescent are temporary employment contract for 20 years faithful also participated. On January $30^{\text {th }}$ (two days later), the Federation of Independent Trade Unions of Egypt formed in the Maidan Tahrir. This federation gathered in Egypt to strike together, and more, they believe that the large-scale strike would clamp position and Mubarak forced him to step down from power. ${ }^{30}$ A collection of postal workers, bus drivers, steel workers, weavers, workers at the same pharmacy also joined, including 6000 workers in the Suez Canal. ${ }^{31}$ This strike must continue to spread to every corner of the Egyptian economy and was followed by several provinces such as: Mansoura, Suez, Luxor, Dairut, Shebin el-Kom, El-Arish, Sohag, Minya, Ismailia, Alexandria and Zagazig. ${ }^{32}$

Although it used to said, that the lower classes only a small role in the fight against the regime, but today's demonstration (January 25 $5^{\text {th }}$, a massive strike action raised fears over the lower classes, of the ruling classes, because it threatening the economics system and also harmful to the Mubarak regime. Finally, right on the second Friday February 11 $1^{\text {th }}$ 2011, at

${ }^{30}$ Sallam, Hesham, Striking Back at Egyptian Workers, Rewriting History, MER259, web: <http://www.merip.org/mer/mer259/strikin g-back-egyptian-workers>, December 11, 2011.

${ }^{31}$ Workers at the heart of the revolution, web: $<$ http://www.socialist.ca/socialistworker/SW 2011/issue532/INT-

Workers_at_the_heart.html>, December 11, 2011.

32 Striking back at egyptian workers, web: <http://www.jadaliyya.com/pages/index /1914/striking-back-at-egyptian-workers>, Nopember 20, 2011. 
6pm(Cairo time, the President of Egypt Hosni Mubarak announced his resignation which was read by Vice President Omar Suleiman and government Mesirpun taken over the Supreme Military Council (SCAF), led by M. Hussein Tantawi.

\section{Conclusion}

At the end of publication of this manuscript, the author'sconclude that the main cause demanded that Mubarak step down as president of Egypt because of two important factors, namely internal and external factors.

\section{a. Internal factors:}

The Economic crisis is a major issue causing the emergence of lowerclass movement in protest. High levels of poverty, unemployment, rising prices of wheat and oil, add a row of misery for the people of Egypt. Thus, with the economic crisis, the legitimacy of Mubarak regime are questionable.

The dominant class in this case has always been an important actor in driving the economy in Egypt, but unfortunately, they better utilize the functions of state power, to legalize their interests of particular individuals or groups. The entrepreneurs would take refuge with the regime for the safety and legality of the businesses that they do. These special protections eventually support a new row of corruptions that resulted in the contamination of Egyptian economic order. At the same time, when the opposition began to increase awareness and to threaten the position of Mubarak, the authoritarian regimes began to make the fight against these oppositions by using martial law $162 / 1958$, to paralyze any action which considered dangerous

Moreover, the manipulation of every election also continued to maintain their position. These things made discontent of lower-class, also forcing the middle class to fight abuses of the class. With the gathering of millions of masses in the Maidan Tahrir, making the group the Mubarak supporters (military), began to turn the bow. The military decided to stay away from Mubarak. Mubarak's alignments attitude over to the new entrepreneurs, will later be the main reason why the military didn't being a defender of the regime while the demonstration happen. 


\section{b. External factors (triggers)}

Globalization certainly makes the role of the media are so important. Succeed in overthrowing the power of Tunisia Ben Ali, a major trigger for neighboring countries do the same action. Mass media like $\mathrm{Al}$ Jazeera, $\mathrm{BBC}$, and some site / web online or microblogging (Youtube, Facebook, Twitter) became a powerful tool to disseminate and inform protests in real-time in this global era. Al Jazeera, be a messenger tools and information divisor important to the people of Egypt or the world. Through this, the protests in January 25 $5^{\text {th }}$, running smoothly and get feedback or response from the international community, such as the U.S. and Europe. At the same time, the internationals come to asking Mubarak to immediately end his power and down from his post as president of Egypt.

At the end of this conclusion, from the title of the journal, it can be seen, that internal factors like the economic crisis, national debt, the capitalist business, corruption, and authoritarian-style regime of behavior, such as; suppression, arrests, violations of human rights, electoral manipulation, etc.., are the reason that causes Mubarak was forced to resign from his post as president of Egypt.

The external factors just the trigger which inspired the people of Egypt to protest. Because in the absence of triggering factors, does not make the Egyptian people do the same as the people of Tunisia done. Both of these factors (internal and external), would still invite multiple interpretations. But the authors believe that the economic factors are the most strongly reason and the cause of Mubarak's falls. Due to rapid economic growth accompanied by the economic crisis may weaken the authoritarian regime. Then, when the economic crisis happen without achieving prosperity in the transition zone, the authoritarian regimes will falling soon. This finally proves the Huntington statements, which authoritarian regimes are not able to meet the economic needs of its people, will be destroyed or uprooted. 
References

Books:

Al-Munazzama,al-Misriyya liHuquq al-Insan, Halat buquq al-insan fi Misr, al-taqrir al-sanawi li al-'am 1996, Cairo, 1997.

Harik, Eliya., Economic Policy Reform, University Press of Florida, 1997.

andSullivanDenis,

Privatization and Liberalization in the

Middle East, The prospects and the fears, Indiana University Press, 1992.

Kassem, Maye, Egyptian politics: the dynamics of authoritarian rule, Lynne Rienner, USA, 2004.

Ouda, Jihad., Negad el-Borai, and Hafez Abu Saada, A Door onto the Desert:Egyptian Legislative Elections of 2000, Cairo, United Group and Friedrich Naumann Foundation, 2001.

R. Vyrynen and T. Ohlson Egypt: Arms Production in the Transnational Context, in Michael Brzoska and Thomas Ohlson, Arms Production in the Third World, London: Taylor \& Francis, 1986.

Samuel P. Huntington, 'Gelombang Demokratisasi Ketiga', translate by Asril Marjohan, Cet: II,
Jakarta, Pustaka Utama Grafiti, No. 328/95, 1997.

\section{Journals:}

David K. Fieldhouse, Western Imperialism in the Middle East, Arab Press Review

Issue No. 1749, September 2003.

Ibn Khaldun Center, Al-Mujtama' ElMadani wa al-Tahawnul El-Dimuqrati fi al-

watan al-arabi, al-taqrir alsanawi 1994 \& 1996, Cairo, 1997, pp. 63-66.

Independent Committee on Election Monitoring (ICEM).Press Statement, November 15, 2005.

International Republican Institute, 2005 Parliamentary Election Assessment in Egypt, International

Republican Institute,(Ed) November 15-21, 2005.

Zaki Moheb, Egyptian Business Elites, pp. 96-100.

\section{Onlines:}

Aladdin Elaasar, Egyptians Rise Against Their Pharoah,Huffington Post, 
January 28, 2011, web: Egypt: Troops Smother Protests, Detain <http://www.londonthenews.c Activists, Human Rights Watch Press, om/news/World/20110128/1 May 5, 2006, web: 9166904/Aladdin-Elaasar$<$ http://www.hrw.org/en/new Egyptians-Rise-Against-TheirPharoah.htm>, October 20,2011 . s/2006/ 05/05/egypt-troopssmother-protests-detainactivists>, Oktober 12, 2011.

Assessment of the Electoral Framework, Democracy Reporting International and

the Egyptian Organization for Human Rights, April 2007, web: <http://www.democracyreporting.org/downloads/repo rts/dri_egypt.pdf $>, \quad$ October 12, 2011.

Corrupt files in the cause of the outbreak of the Revolution, web:

$<$ http://holafootball.blogspot. com/2011/02/corrupt-files-incause-of-outbreak-of.html>, 25

November 2011.

Corruption index 2010 from Transparency

International: find out how each country compares, web: <http://www.guardian.co.uk/ news/datablog/2010/oct/26/c orruption-index-2010transparency-international $>$, November 25,2011.

Egyptian Revolution, web:

$<$ http:// en.wikipedia.org/wiki /2011_Egyptian_revolution>, Pebruary04, 2012.

Ezzat Dina, Not Strictly Public, AlAhram Weekly, March 9, 2006, bisa diakses

di:

<http://weekly.ahram.org.eg/2006/78

5/index.htm>, April 12, 2011.

Facebook post that sparked Egypt revolution, web:

$<$ http://ibnlive.in.com/news/f acebook-post-that-sparkedegypt-revolution/1423282.html>, December 10, 2011. Kirkpatrick, David D, David E, Sanger, A Tunisian-Egyptian link that shook

Arab history. The New York Times, February 13, 2011, web: <http://www.nytimes.com/20 11/02/14/world/middleeast/1 4egypt-tunisia- 
protests.html?_r=1>,

October20, 2011.

Letter from Human Rights Watch to Secretary of State Condoleeza Rice,

Regarding Department of State

Comments on Egyptian

Elections, December 01, 2005, web:

$<$ http://www.hrw.org/en/new

s/2005/12/01/letter-secretary-

state-condoleeza-rice-about-

department-state-comments-

egyptian-elec $>$,

tanggal:

September 12, 2011.

Mona Eltahawy, On Khaled Said and his effects on Egyptian bloggers and activists, Huffington Post, June 25 , 2010,web:

$<$ http://mediaoriente.com/20

10/06/25/on-khaled-said-and-

his-effects-on-egyptian-

bloggers-and-activists $/>$,

January20, 2012.

More than 50 Journalists and Media

Workers Harassed, Some Beaten while

Covering Elections, Reporters

Without Borders, December 9, 2005 , web:

$<$ http://en.rsf.org/egypt-

more-than-50-journalists-and-

media-09-12- 2005,15881.html>, October 12, 2011.

Obama optimistic about Egypt as negotiators make concessions. AHN. February

9, 2011, web:

<http://gantdaily.com/2011/0

2/07/obama-optimistic-about-

egypt-as-negotiators-make-

concessions/>, October 20,

2011.

Ralph Miliband, Socialist Advance in Britain, The Socialist Register 1983, p.

103-120. Web:

$<$ http://www.marxists.org/arc

hive/miliband/1983/xx/advan

ce.htm>, April 04,2012.

Sallam, Hesham, Striking Back at Egyptian Workers, Rewriting History,

MER259, web:

<http://www.merip.org/mer/

mer259/striking-back-egyptian-

workers>, December 11, 2011.

Security Forces Attack Opposition

Demonstrators,Human Rights Watch Press,

August 01, 2005, web: $<$ http://www.hrw.org/en/new s/2005/08/01/egypt-securityforces-attack-oppositiondemonstrators>, October 12, 2011. 
Striking back at egyptian workers, web:

<http://www.jadaliyya.com/pa

ges/index/1914/striking-back-

at-egyptian-workers>,

November 20,2011.

The 2011 Time 100, web:

<http://www.time.com/time/

specials/packages/article/0,288

04,2066367_2066369,00.html>,

December 10, 2011.

The Arab Spring's Cascading Effects, web:

<http:// www.miller-

mccune.com/politics/the-cascading-

effects-of-the-arab-spring-28575/>,

December 10, 2011.

The Report: Egypt 2007, Oxford

Business Group, January 2007, web:

<http://www.oxfordbusinessg

roup.com/product/report/rep

ort-emerging-egypt-2007>,

October 20, 2011. 